\title{
Profitability of litchi production in Dinajpur district of Bangladesh
}

\author{
R. Akter*, M. Serajul Islam and H. Jahan \\ Department of Agricultural Economics, Bangladesh Agricultural University, Mymensingh-2202, Bangladesh \\ *Email: rumanaakterrita4013@gmail.com
}

\begin{abstract}
This paper examined the profitability of litchi production in Dinajpur district of Bangladesh. Both primary and secondary data were used to accomplish the study. The primary data were collected during production period of litchi from February to May, 2015 through direct interviews with litchi growers. In total 60 litchi growers were interviewed from four villages of Dinajpur district to collect the necessary information. Profitability analysis was employed for analyzing the data and testing the hypotheses of the study. The life cycle of litchi is divided into five parts; juvenile or non-bearing stage, early bearing stage, young bearing orchards, full bearing orchards and old declining orchard, respectively. Per acre production in a season of its full bearing stage was considered for this paper. The production of litchi largely depends on its age and weather during the four month of litchi production. The major findings of the present study revealed that per acre net return of litchi considering selected varieties was Tk. 171624 based on one production period (February to May) in its full bearing stages which means litchi production is a profitable enterprise.
\end{abstract}

Keywords: Profitability, Litchi production, Dinajpur

\section{Introduction}

Litchi (Litchi chinensis) is regarded as one of the kings of sub-tropical fruits and famous for its excellent quality such as juiciness, slightly sour-sweet taste, characteristics pleasant flavor and attractive colour. Litchi is a highly priced, popular and major table fruit in Bangladesh. It has a great demand among all classes of people. Litchi is a non-climacteric fruit. The tree reaches up to $12 \mathrm{~m}$ or more in height. When grown under congenial climatic conditions, radial diameter of the tree's canopy is also nearly $12 \mathrm{~m}$. The branches are crooked or twisted, low-hanging and spreading, forming a head broader than the height. In some varieties, the branches are fairly straight and more or less upright, forming a compact, rounded head. In some cases, however, the tree assumes fairly wider spreading (horizontal) growth than its height. During initial years of growing, pace of tree's vegetative growth is highly influenced by growing environment and nutrition (Wills et al., 2004).

The total area of Dinajpur district is $3,437.98 \mathrm{~km}^{2}$.It is in the northern part of Bangladesh. Large number of litchi produces here because its geographical location, soil condition and rainfall are suitable for litchi production. The litchi growers are interested in litchi production for its economic benefit. Dinajpur district has an average elevation of 37 meters above the sea. The study areas were belong to the old Himalayan piedmont plain of Agro-Ecological Zones (AEZ) (BBS, 2013).

Table 1 shows that litchi production has increased gradually in Bangladesh over the years. Though litchi grows more or less all over the country, it gives higher production in Dinajpur district.

There are several studies on litchi production, its growth and its disease but no adequate studies on profitability of litchi production as such it felt that a study on profitability of litchi could be of much importance. It is hoped that the findings and specific suggestion from the study will help the producers, traders, consumers, extension workers and researchers in their efforts for the improvement of production and marketing of litchi in Bangladesh. Thus, the study aims to determine the economic return of producing litchi on per acre per season basis. 
Table 1. Production of litchi by district (in metric tonnes)

\begin{tabular}{c|c|c|c|c|c|c|c}
\hline District & $\mathbf{2 0 0 6 - 0 7}$ & $\mathbf{2 0 0 7 - 0 8}$ & $\mathbf{2 0 0 8 - 0 9}$ & $\mathbf{2 0 0 9 - 1 0}$ & $\mathbf{2 0 1 0 - 1 1}$ & $\mathbf{2 0 1 1 - 1 2}$ & $\mathbf{2 0 1 2 - 1 3}$ \\
\hline Bandarban & 125 & 115 & 144 & 171 & 181 & 204 & 504 \\
Chittagong & 1495 & 1534 & 2446 & 1932 & 1831 & 2285 & 2560 \\
Comilla & 475 & 380 & 411 & 468 & 475 & 406 & 563 \\
Khagrachhari & 475 & 357 & 555 & 969 & 1228 & 1268 & 1670 \\
Noakhali & 520 & 231 & 220 & 248 & 209 & 198 & 300 \\
Rangamati & 508 & 891 & 1294 & 1393 & 1783 & 670 & 1090 \\
Sylhet & 1125 & 1469 & 1291 & 1268 & 1679 & 1331 & 2030 \\
Dhaka & 1700 & 1837 & 2681 & 2166 & 2138 & 1581 & 2115 \\
Faridpur & 1040 & 1395 & 1401 & 1379 & 1337 & 1239 & 3000 \\
Jamalpur & 1265 & 1392 & 1434 & 1468 & 1495 & 1655 & 2519 \\
Dinajpur & $\mathbf{9 4 6 5}$ & $\mathbf{9 2 4 5}$ & $\mathbf{1 0 1 9 1}$ & $\mathbf{1 3 2 2 6}$ & $\mathbf{1 2 3 6 7}$ & $\mathbf{1 3 1 3 9}$ & $\mathbf{1 3 8 8 3}$ \\
Mymensingh & 3525 & 4044 & 7894 & 8665 & 9187 & 1538 & 1748 \\
Tangail & 655 & 688 & 742 & 786 & 816 & 850 & 912 \\
Barisal & 460 & 337 & 549 & 564 & 576 & 572 & 740 \\
Jessore & 2005 & 1493 & 1361 & 1385 & 1374 & 1461 & 1787 \\
Khulna & 2006 & 1493 & 1361 & 1385 & 1374 & 1461 & 1787 \\
Kustia & 3155 & 2920 & 2991 & 3234 & 4518 & 3451 & 3890 \\
Patuakhali & 95 & 96 & 100 & 99 & 94 & 97 & 150 \\
Bogra & 720 & 706 & 686 & 760 & 939 & 979 & 1115 \\
Rangpur & 1115 & 1204 & 2984 & 2886 & 2858 & 3029 & 3952 \\
Pabna & 4770 & 4631 & 4687 & 5779 & 4986 & 6423 & 7639 \\
Rajshahi & 4900 & 4608 & 5716 & 9226 & 7998 & 6427 & 7880 \\
Kishoreganj & 1620 & 1786 & 2881 & 2112 & 2112 & 2178 & 2681 \\
Bangladesh & $\mathbf{4 3 5 6 5}$ & $\mathbf{4 3 7 6 7}$ & $\mathbf{5 5 2 8 8}$ & $\mathbf{6 4 9 9 5}$ & $\mathbf{6 6 4 6 6}$ & $\mathbf{5 6 6 8 7}$ & $\mathbf{6 8 5 8 2}$ \\
\hline
\end{tabular}

Source: BBS, 2013.

\section{Different stages of the life of a litchi tree}

From previous studies it is known that the entire life span of a litchi tree can be divided into five distinct stages for adoption of suitable cultural practices to manage the orchard for maximum return. The stages are important for the production of litchi that are described below:

Juvenile or Non-bearing stage: Litchi trees in the age group of 1 to 5 years usually are belonging to juvenile or non-bearing. Some trees may start bearing in the fifth year or even fourth year, but by 6year, majority of the trees in an orchard come into bearing. In seedling litchi, this juvenile period may last from 6 to 10 years, while in layered plants, it lasts for 4 to 5 years.

Early bearing stage: The litchi trees between 6 and 10 years of age are in the early bearing stage. This is a delicate stage when a major transformation from vegetative to reproductive growth takes place. In this stage, the fruiting of litchi start slightly and the branches of litchi start to spread around the tree.

Young bearing orchards: This is the very delicate stage of orchard management where more visionary approach should be followed in skillful manner. During young bearing stage between 11 and 20 years, plant needs more nutrients for proper growth and bearing.

Full bearing orchard: Attaining the age of 20 years, litchi tree enters into the phase where vegetative growth and fruiting are relatively balanced and the trees acquire nearly full canopy. The age of litchi tree ranges between 21 and 70 years. This phase is known as full bearing stage or commercial bearing period. At this stage, tree reaches its full yield potential and continuously produces almost similar yield until it is 70 years old. Therefore, a well-managed orchard will be commercially highly productive for a period of 50 years. The litchi trees are equally remunerative even after attaining the age of 100 years. The main aim of orchard management at this stage is to produce maximum yield with maximum feeding. At this stage, different fertilizers should be applied at different periods of cycle. 
Old declining (senile) orchards: This stage comes usually after 70 years or thereafter when symptoms of ageing are becoming apparent. When orchard is not managed properly for a prolonged period the decline may start quite early i.e. after 45 or 50 years of establishment. Litchi tree has strong renewal ability therefore; the old and unproductive orchards can be rejuvenated for further higher production. In this stage litchi tree can give production but it need extra care.(Singh et al., 2012)

\section{Data sources and methodology}

The present study was based on field level primary data collected from litchi orchard owners through farm survey method. The main purpose of the survey was to collect and analyze field level costs and returns data from the litchi orchard owners. Preliminary investigation showed that in Dinajpur Sadar and Kaharole Upazila of Dinajpur district, farmers are more interested in litchi production rather than other crops. Due to high land of these areas, litchi tree gives better production. Therefore, the aforementioned are as were purposively chosen, where litchi production is better rather than other areas of the country.

In the study area different varieties of litchi are produced namely Bombai, Bedana, Madrazi, Chaina-2, Chaina-3, and Mozaffari etc. But Bombai is the most popular among all the varieties because of its higher production and good taste. However Bombai, Bedana, Madrazi, Chaina-2, and Chaina-3 were selected for this study. Data were collected through the period from February to May 2015.

The data and information, collected from field surveys, interviews, discussion and communications were coded, summarized and processed for the analysis. Inputs used in the study areas were both purchased and family supplied. The input items were valued at the existing market price in the area during survey period. The profitability analysis was done on the basis of full bearing stage of litchi.

\section{Descriptive Analysis}

Descriptive technique is well known and widely used techniques to show the result of farm management research because it is simple, convenient and very easy to understand. It is the technique that is commonly followed to find out the crude association or different between inputs and output (Sarkar, 2012). Per acre profitability of litchi production from the view of individual farmers was measured in terms of gross return, gross margin and net return.

Gross Return: Gross return was calculated by multiplying the total volume of output of an enterprise by the average price in the harvesting period (Dillon and Harddakar,1993). Here the output includes the physical quantity of main product. The following equation was used to estimate gross return in producing litchi:

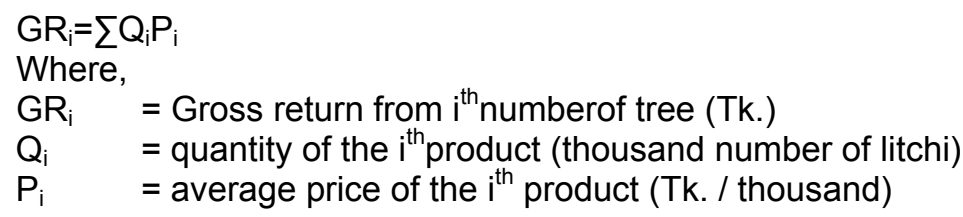

Gross Margin: Gross margin calculation was done to have an estimation of the difference between total return and variable costs. The analysis is also easily understandable because of its simplicity. The following equation was used to assess gross margin:

$\mathrm{GM}=\mathrm{TR}-\mathrm{TVC}$

Where,

$\mathrm{GM}=$ Gross margin;

TR = Total return; and

TVC $=$ Total variable cost. 
Net Return: Net return analysis consider fixed cost of land rent, interest on operating capital, depreciation of farm implements etc. Net return was calculated by deducting all costs (variable and fixed) from gross return. To determine the net return of litchi production, the following equation was used in the present study:

$\Pi=\sum P_{M} Q_{M}-\sum\left(P_{x i} X_{i}\right)-T C$

Where,

$\Pi \quad=$ Net Return

$\mathrm{P}_{\mathrm{M}} \quad=$ per unit price of product (Tk. /1000 litchi)

$\mathrm{Q}_{\mathrm{M}} \quad=$ Quantity of Production per acre (Number of litchi in thousands)

$P_{\mathrm{xi}} \quad=$ Per unit price of $i^{\text {th }}$ inputs (Tk.)

$X_{i}=$ Quantity of $i^{\text {th }}$ inputs per acre $(\mathrm{kg})$

TC $=$ Total fixed cost (Tk.), and

$\mathrm{i} \quad=1,2,3 \ldots \ldots . \mathrm{n}$ (number of inputs)

\section{Results and Discussion}

This section reveals the estimation and analysis of costs and returns from litchi orchard. Profitability is one of the major criteria for determination of acceptance of a crop. This section analyses per acre total costs, gross return, gross margin and net return of litchi production in the areas. All these costs and returns were calculated for the duration of four months (February to May) operation of growing litchi.

Estimation of production cost of litchi: In calculating the production costs, the components that were considered include human labour, fertilizers, irrigation, insecticides, cultural and management practices, interest on operating capital and land use cost. Variable costs are the cost of using the variable inputs that change with the level of production. Fixed costs are those which do not change in magnitude as the amount of output changes and are incurred even when production is not undertaken. These costs do not vary with the level of production. In the present study, inputs such as human labour, organic and inorganic fertilizer, irrigation, pesticides and vitamin etc. were considered as variable costs. On the other hand, interest on operating capital and land use cost (with litchi tree) were considered as fixed costs.

Rental value of land (with litchi tree): Rent of the land (with litchi tree) varies from different period of time (usually it varies from 1 to 6 years). Land use cost varies from one place to another depending on the location, soil fertility, topography of soil etc. In the study area, rental value of land also varies depending on number of trees per acre and age of the litchi tree within the orchard.

Cost of human labour: Human labour was measured in terms of man-day unit which consisted of 8 hours of work by an adult man. For child and women, man equivalent hours were estimated. This was computed by covering all women and children hours into man equivalent hours by assigning a ratio of 2 children=1.5 women=1 adult man (Yang, 1965). The valuation of purchased labour was done as the nominal cash wages paid plus the monetary value of kind payments provided by the farmers. Average wages of the purchased labour was taken as the opportunity cost of home supplied labour. The labour cost on different operations is presented in Table 2.

Table 2. Operation wise costs of labour in litchi production per acre

\begin{tabular}{lcc}
\hline Labour types & Operation wise cost (Tk./acre) & Percent of total cost \\
\hline Fertilizer application & 900 & 6.67 \\
Pesticide application & 3375 & 25 \\
Irrigation & 1350 & 10 \\
Harvesting & 7875 & 58.33 \\
\hline Total & $\mathbf{1 3 5 0 0}$ & $\mathbf{1 0 0}$ \\
\hline
\end{tabular}

Source: Akter (2015, p.59) 
Cost of fertilizer: In litchi production, fertilizer was applied mainly after harvesting. Sometimes small quantity of fertilizer applied before fruiting of litchi. Fertilizers have slight importance in litchi production. Farmers used different types of fertilizers such as urea, TSP, MP, Boron, Zink, furatonjenofuran, and organic manure etc. Application of fertilizer needs different activities including digging the soil so cost of labour in fertilizer application(Table 2) is more than total cost of fertilizer. The total cost of fertilizer was Tk. 512.2 in case of litchi production (Table 3 ).

Table 3. Costs of fertilizer per acre

\begin{tabular}{c|l|c|c|c}
\hline SL. No. & Types of fertilizer & Quantity (kg) & Price per unit (Tk./kg) & Total cost (Tk.) \\
\hline 1 & Organic Manure & 1.9 & 3 & 5.7 \\
2 & Urea & 1.7 & 16 & 27.5 \\
3 & TSP & 1.4 & 25 & 35 \\
4 & MP & 1.5 & 16 & 24 \\
5 & Others (Zink) & 2.8 & 150 & 420 \\
\hline Total
\end{tabular}

Source: Akter (2015, p.59)

Cost of pesticide: Litchi growers use different kinds of pesticide to protect their litchi from the attack of pest and diseases. Name of some pesticides which are used in litchi production are riva, ripcord, nitro, companion, carbondazin, and alba etc. Cost of pesticides was calculated on the basis of actual amount of money paid by the farmers.

Cost of irrigation: Irrigation is an essential input for cultivating litchi. Most of the farmers had to pay mechanical irrigation water charges and they used manual labour for irrigation. In the study area, most of the farmers used Shallow Tube Well (STW) for irrigating their litchi orchard. In production period, litchi orchard needs 5 to 7 times irrigation.

Cultural and management operation: Litchi is a fruit crop. It needs extra care than cereals and vegetables. Watch man is must in a litchi orchard at the time of fruiting to harvesting to protect the litchi fruit against thief. Year wise extra cost also needed in litchi production such as pruning of branch, fence around the orchard (if the branch lies near to the soil), and covering the fruit for protecting from bird etc. on the basis of this cultural and management practices.

Interest on operating capital: Interest on operating capital was calculated by taking into account the costs incurred on all field operations but excluding those items for which interest had already been calculated. Interest on operating capital was worked out on the basis of opportunity cost principle, that is, it was assumed that if the farmers borrowed the money from a bank, they had to pay the interest at the same rate. Therefore, the standard formula for calculation of operating capital is as follows (Miah, 1987): Interest on operating capital $(\mathrm{IOC})=$ Alit.

Where,

Al = average investment(total investment/2)

$\mathrm{i} \quad=$ Interest rate which was 11 percent during the study period; and

$\mathrm{t} \quad=$ length of the period of litchi production (Falgun to Jaistha=4 months)

The total cost was calculated by adding up all the above cost items and are presented in Table 4 .

Table 4. Costs of litchi production per acre per season

\begin{tabular}{c|l|c|c}
\hline SI. No. & Items & Amount (Tk.lacre) & Percent of total (\%) \\
\hline a. & Human labour & 13500 & 9.69 \\
b. & Fertilizer & 512.2 & 0.36 \\
c. & Pesticide & 5715 & 4.10 \\
d. & Irrigation & 1392 & 0.99 \\
e. & Cultural and management practices & 16515 & 11.86 \\
f. & Rental value of land & 93332 & 67.0 \\
g. & Interest on operating capital & 8279.52 & 5.94 \\
\hline Total cost & $\mathbf{1 3 9 2 4 5 . 7 2}$ & $\mathbf{1 0 0}$ \\
\hline
\end{tabular}

Source: Akter (2015, p.62) 
Gross Return: Gross return from litchi cultivation is the sum of the returns from different verities of litchi. For the convenience of calculation, the age of litchi tree belongs the age bracket of 15 to 30 years was used to calculate the gross return from litchi production. Among all the verities cultivated in the study area, Bombai gives the highest production, Madrazi gives lower litchi production but it gives early production of litchi and it also disease intensive. China-2 and Bedana have got the higher price. China-3 gives lower production in the study area. Madrazi variety gives high amount of production but it is less tasty than other varieties. Its seed is larger than pulp. So, price of madrazi is lower than other varieties of litchi. Table 5 shows the average gross return estimated for 80 litchi trees in one acre area.

Table 5. Gross return per acre earned from litchi orchard per season

\begin{tabular}{c|c|c|c|c|c}
\hline $\begin{array}{c}\text { SL } \\
\text { No. }\end{array}$ & Litchi variety & $\begin{array}{c}\text { Number of } \\
\text { tree planted }\end{array}$ & $\begin{array}{c}\text { Quantity (1000 } \\
\text { litchi/tree) }\end{array}$ & $\begin{array}{c}\text { Price (Tk.I } \\
\text { 1000 litchi) }\end{array}$ & $\begin{array}{c}\text { Return from different } \\
\text { variety (Tk.) }\end{array}$ \\
\hline 1. & Bombai & 53 & 1.8 & 2400 & 228960 \\
2. & Madrazi & 17 & 1.7 & 1300 & 37570 \\
3. & Bedana & 5 & 1.5 & 4000 & 30000 \\
4. & Chaina 2 & 3 & 1.3 & 3000 & 11700 \\
5. & China 3 & 2 & 0.4 & 3300 & 2640 \\
\hline \multicolumn{7}{r}{ Total return }
\end{tabular}

Source: Akter (2015, p.63)

Gross Margin: Gross margin is the difference between the gross return and total variable costs. The argument for using gross margin analysis is that the farmers of Bangladesh are more interested to know their return over variable costs.

Table 6. Cost and profit of litchi production per acre per season (considering varieties)

\begin{tabular}{cllc}
\hline SL No. & Particulars & Amount (Tk.) \\
\hline 1. & Total variable cost & 37634.20 \\
2. & Total fixed cost & 101611.52 \\
3. & Total cost (1+2) & 139245.72 \\
4. & Gross return & 310870 \\
5. & Gross margin(4-1) & 273235.8 \\
\hline & Net return(4-3) & $\mathbf{1 7 1 6 2 4 . 2 8}$ \\
\hline
\end{tabular}

Source: Akter (2015, p.63)

Net Return: Net return is obtained by deducting all costs from gross return. Table 6 reveals that per acre net return of litchi considering all varieties is Tk. 171624.28 which means litchi production is profitable.

\section{Conclusion}

Litchi production provides high return to its growers. Higher yield of litchi largely depends on climate of that particular year, timely operation and appropriate level of inputs use are also important for achieving higher profit. But due to lack of training litchi growers are not aware about timely and efficient use of inputs. Cultural management as well as varietal selection is important for improving yield and economic return of litchi production. Accordingly, DAE and other related organizations should come forward to help farmers in this regard. The scheme of litchi insurance may be introduced to cover the risk and uncertainty prevailed in litchi production. It is stated that litchi is a profitable enterprise. But litchi is a highly perishable fruit and there is no litchi processing center in this area, therefore, litchi producers use different medicines to preserve litchi which are harmful to health. Establishment of a processing center for this kind of high value crop is essential in this area. 
Akter et al.

\section{References}

Akter, R. 2015. Economic Study on Litchi Production in Selected Areas of Dinajpur District, MS Ag. Econ. Thesis, submitted to the Department of Agricultural Economics, Bangladesh Agricultural University, Mymensingh.

BBS. 2013. Bangladesh Bureau of Statistics, Statistical Year Book of Bangladesh, Agriculture Statistical Wing, Ministry of Planning, Government of the Peoples Republic of Bangladesh, Dhaka.

Dillion, J.L. and Hardaker, J.B. 1993.Farm Management Research for Small Farmer Development, University of New England, Australia.

Miah, M.T.H. 1987. Appraisal of Deep and Shallow Tubewell Irrigation Project in the Tangail District in Bangladesh. Ms Thesis, Department of Agricultural Economics and Business Management, University of New England, Australia.

Sarkar, M.A.R. 2012. A study on Economic Efficiency and Sustainability of Wheat Production in Selected areas of Dinajpur District. M.Sc. Ag. Econ. Thesis, Bangladesh Agricultural University, Mymensingh.

Singh, G., Nath, V., Pandey, S. D., Roy, P.K. and Singh, H.S. 2012. The Litchi, Food and Agricultural Organization of the United Nations, New Delhi, India. [http://tmnehs.gov.in].

Wills, R.H.H., Lee, T.H., Graham, D., Mcglasson, W.B. and Hall, E.G. 2004. Post harvest. An Introduction to the Physiology and Handing of Fruits and Vegetables. Granada Publ. Ltd. London, pp.161.

Yang, W.Y. 1965.Methods of Farm Management Investigations for Improving Farm Productivity.Food and Agricultural Organization of the United Nations, Rome, Italy. 